\title{
Exploring the Association Between HIV and Violence: Young People's Experiences with Infidelity, Violence And Forced Sex in Dar es Salaam, Tanzania
}

By Heidi Lary, Suzanne Maman, Maligo Katebalila, Ann McCauley and Jessie Mbwambo

Heidi Lary is a project director, School of Nursing, and Suzanne Maman is assistant professor, Department of International

Health, Bloomberg School of Public

Health, both at Johns

Hopkins University,

Baltimore, MD, USA.

Maligo Katebalila is

research assistant and

Jessie Mbwambo is

lecturer, Department of Psychiatry,

Muhimbili University College of Health Sciences, Dar es Salaam, Tanzania. Ann McCauley, of the International Center for Research on

Women, is seconded to the Horizons Project, Washington, DC, USA.

\begin{abstract}
CONTEXT: Prior research has shown a strong correlation between HIV infection and a history of intimate partner violence, particularly among young women. However, the role violence plays in the sexual relationships of young people in Sub-Saharan Africa is not well understood.
\end{abstract}

METHODS: Locally trained interviewers conducted semi-structured interviews with 40 young men and 20 young women aged 16-24 who were recruited from public venues in Dar es Salaam, Tanzania.

RESULTS: The participants described complex interactions among violence, forced sex and infidelity in their sexual relationships. Men who were violent toward female partners also frequently described forced sex and sexual infidelity in these partnerships. Men with multiple concurrent sexual partners reported becoming violent when their female partners questioned their fidelity, and reported forcing regular partners to have sex when these partners resisted their sexual advances. Youth who felt that violence and forced sex could not be justified under any circumstances were often those who had not yet initiated sexual relationships or who were in monogamous partnerships.

CONCLUSIONS: The association between HIV and violence identified among young people in prior research may be partially explained by their experiences with infidelity and forced sex in their intimate partnerships. HIV prevention interventions that fail to take into account the infidelity, violence and forced sex frequently involved in youth's sexual relationships will have a limited impact.

International Family Planning Perspectives, 2004, 30(4):200-206

Studies throughout the world have found an association between gender-based violence and HIV risk behaviors and HIV serostatus. ${ }^{1}$ Research conducted in Soweto, South Africa, provided evidence supporting this association by finding that male partners who are abusive are more likely than those who are not to be HIV-positive. ${ }^{2}$ Moreover, a quantitative study conducted by our research team in 1999 to explore the association between HIV and violence among women at an HIV voluntary counseling and testing clinic in Dar es Salaam, Tanzania, found a strong and consistent association. ${ }^{3}$ HIV-infected women reported significantly more sexual violence in their relationships, a larger mean number of physically violent partners in their lifetime and a larger number of physically violent episodes with their current partner.

An association between women's history of violence and their HIV serostatus has been found in other settings. A study conducted in Kigali, Rwanda, revealed that women with a history of sexual coercion were more likely than those without such a history to be HIV-positive. The study also found that violent male partners had elevated odds of being HIVpositive. ${ }^{4}$ In the Soweto study mentioned earlier, women's risk of being HIV-positive was associated with both intimate partner violence and high levels of male control in the current relationship after the effects of women's risk behaviors were accounted for. The authors postulated that abusive men are more likely than nonabusive men to be HIV-positive and to practice risky sexual behaviors with their partners. ${ }^{5}$
In our previous research in Tanzania, we found a particularly strong association between history of violence and HIV serostatus among women younger than 30. In that agegroup, the odds of reporting physical violence with a current partner were 10 times as high among HIV-positive women as among HIV-negative women. ${ }^{6}$ This association between HIV and violence among youth in particular has since been documented by researchers in other countries. ${ }^{7}$

\section{Youth and HIV/AIDS in Tanzania}

The United Republic of Tanzania, located in Southeastern Africa on the coast of the Indian Ocean, is home to a population of more than 36 million that is growing at almost $2 \%$ annually. ${ }^{8}$ With estimated per capita income of about $\$ 250$ per year, Tanzania is considered one of the world's poorest countries. On average, only $47 \%$ of boys and $51 \%$ of girls of primary school age attended school between 1992 and $2001 .^{9}$

Tanzania is one of the Sub-Saharan African countries most affected by HIV, with overall prevalence of about $10 \% .{ }^{10}$ Nationally, an estimated $17 \%$ of females and $8 \%$ of males aged 15-19 years are HIV-positive. ${ }^{11}$ In 2001, 25\% of women younger than 24 attending a health clinic in Dar es Salaam were infected. ${ }^{12}$ Moreover, a 2001 study of young blood donors in the Arusha, Iringa, Kagera and Morogoro regions found HIV prevalence of $15-18 \% .^{13}$

Unprotected sex and the rarity of monogamous partnerships are fueling the rapid expansion of the HIV epi- 
demic among youth. A 2001 study found that $50 \%$ of males and $25 \%$ of females reported that they had had one or more casual sexual partners in the past year, and just $35 \%$ of males and $24 \%$ of females reported using a condom during their last sexual encounter with a casual partner. ${ }^{14}$ In a study conducted in Dar es Salaam, more than $50 \%$ of young men and women reported having had more than one partner in the previous six months, and $23 \%$ of men and $17 \%$ of women reported ongoing relationships with more than one partner. ${ }^{15}$ Despite high levels of knowledge about the effectiveness of condoms against HIV infection, only 10\% of young people reported using them regularly.

Men in Tanzania, as in many other areas of the world, usually determine when, with whom and under what circumstances they have sex with their partners. ${ }^{16}$ Most young women cannot freely choose safer sexual practices or refuse unsafe sexual activity, but instead must negotiate within unequal social relationships. ${ }^{17}$ Gender expectations limit young women's power to negotiate safe sexual behaviors in their relationships. The impact of the power dynamics between adolescent women and men in sexual relationships on women's ability to negotiate safe sexual relations has been well described in contexts with relatively low rates of HIV infection. ${ }^{18}$ However, we have yet to fully understand how these power dynamics play out in contexts such as Tanzania, where up to $25 \%$ of adolescents may be infected.

Given the heightened vulnerability of Sub-Saharan African youth to HIV and the strong association found between HIV and violence, particularly among youth, a better understanding of the role of violence in the sexual relationships of young people is needed. In prior research, there has been little attention to young men's perspectives on these issues. Qualitative research carried out with adolescent males in Latin America, Asia, North America and Sub-Saharan Africa suggests that attitudes that condone viewing women as sexual objects, seeing sex as performance-oriented and justifying sexual coercion as acceptable begin in adolescence. ${ }^{19}$ This finding provides a strong rationale for efforts to work with younger men on issues of sexual and reproductive health.

The literature on programs related to reproductive health, HIV/AIDS and violence that target young men is small but growing. Few rigorous evaluations of such programs exist. This article, which reports on an intervention study with young men in Dar es Salaam, is a response to this gap in the literature. It describes data gathered in the first phase of the project, during which we conducted in-depth interviews with young men and women in the community to explore the links between HIV and violence from the perspective of youth.

\section{METHODS}

In July through December of 2003, we carried out in-depth interviews with 40 men and 20 women aged $16-24$ years. The goal of this study, which was conducted in collaboration with colleagues from the Muhimbili University College of Health Sciences in Dar es Salaam, was to describe the attitudes and behaviors of youth, particularly young men, regarding sex, violence and gender expectations within their own intimate relationships. We used an iterative data collection approach, which allowed the team to refine and redefine the questions central to understanding the interplay between violence and HIV in these young people's lives. To determine if new thematic areas needed to be explored with future respondents, the principal investigators and technical adviser combed new information as it was collected, transcribed and entered, and offered immediate feedback to the research team and interviewers. Because of this process, the content of the field guides the interviewers used was revised in response to the data that emerged in successive waves of interviews. The research protocol, field guides and consent forms were reviewed and approved by the Johns Hopkins Bloomberg School of Public Health's Committee on Human Research and the Muhimbili College of Health Sciences' ethics board.

The two interviewers, university graduates with sociology degrees and prior research experience, were given an intensive two-week course on qualitative research methods, proper interviewing technique and techniques for eliciting sensitive information. All staff involved in the project were trained in and tested on their understanding of and respect for research ethics.

Youth were recruited from public venues in one of the 12 wards of Dar es Salaam. These venues included sports grounds, marketplaces, bus depots and bars. Venues were chosen during the participatory mapping exercise, which consisted of developing an extensive map of the community and its most prominent youth gathering venues on the basis of information gathered from adults and youth in the community. The ward from which the youth were drawn is demographically typical of Dar es Salaam. Although information on socioeconomic status was not gathered from each participant, the community in general tends to be lower middle class.

To recruit participants, interviewers screened young men and women in the venues identified through the community mapping exercise. Those who were 16-24 and resided in the community were asked to participate in this study. Most of the participants were currently in intimate relationships with at least one partner. Most of the men who were interviewed had finished at least seven years of schooling, whereas the majority of women had not completed their primary education.

The semi-structured interviews were based on a qualitative field guide that highlighted major topics for discussion and suggested probes having to do with violence, HIV and sexual relationships. The interviewers were trained to use the qualitative instruments as guides rather than as standardized survey instruments. They encouraged informants, through effective probing, to expand on the topics on which they indicated more knowledge and experience. Thus, not all questions on the field guides were asked of all informants. Interviews lasted about 60-90 minutes and were tape recorded after acquiring the participant's consent. 
The audiotapes were transcribed into Kiswahili text, translated into English and entered into a word processing program. The data were first exhaustively reviewed by the entire research team for main themes and then individually by the principal investigators and the technical adviser. They were then coded for retrieval and analysis using the NUD*IST program. Second, matrices of the interconnections of the three areas of interest were constructed to condense and organize the data and make cross-informant analysis easier. Themes were generated to represent the ideas or experiences of a large proportion of informants. We summarized the key themes that emerged from the interviews and selected quotations that represent these themes.

\section{RESULTS}

\section{Context of Sexual Relationships}

It is important to understand the context of sexual relationships among youth in this setting before trying to disentangle the links among HIV, violence and infidelity. These links may have their roots in the gender norms, expectations and relationship structures that characterize the sexual relationships of young people.

- Sex is the basis of intimate relationships. Young people report that to be considered intimate partners, a young man and woman must have sexual intercourse. Almost unanimously, the men say that a woman must be willing to have sex if she wants to be considered more than a friend:

"How can she be my partner without making love? To know that she loves you and she's your partner you must make love; that's why I convinced her."-unmarried 24-yearold male

When asked why they had sex the first time with their present partner, young men explained that sex was their primary reason for starting the relationship. Young women, however, speak of other reasons for initiating intimate relationships, including love, financial reasons and identifying prospective husbands. The reality that young women in this community are focused on finding husbands cannot be underestimated in terms of its implications for the types of sexual relationships they entertain. An unmarried 20-year-old woman explained very clearly that she had sex in exchange for a marriage proposal:

Participant (P): "I didn't even want him in the beginning."

Interviewer (I): "So why did you have sex with someone you didn't want?"

P: "My sister-in-law was telling me that her brother wanted to marry me and then I knew that I had found someone to marry me."

Young men are aware of young women's motives for entering sexual relationships and often take advantage of this to initiate sexual relationships:

"For now many youths, including me, like to tempt the girl, telling the girl, "I love you very much." That's a lie, because when you tell her that you love her, your aim is to make love to her. It's not that you love her so that you marry her. You persuade her, lie to her somehow."-unmarried 20year-old male
- Opportunities for relationships are tightly controlled. The opportunities for young men and women to meet in this community are tightly controlled by parents and other older family members. As a consequence, young people usually meet their partners in school or through mutual friends or family members. They have to be creative in identifying opportunities and places to meet their partners for sex, because almost all unmarried women live with their parents and most young men live either with their parents or in a shared space with other men. Often young partners meet in the house of the man's friend, in the man's house if he has one of his own, or in a rented room in a guesthouse. When young couples do find an opportunity and place to meet, they often have little time together; they report that their main aim at such meetings is to have sexual intercourse. - Young women are expected to be settled, forgiving and enduring. Community gender norms encourage and promote male initiation of sex and simultaneously limit women's ability to express their own sexual needs and desires. Young women report feeling reluctant to initiate sex with their partners for fear of being considered immoral and sexually aggressive.

"Often it's a man who persuades; it's difficult for women and it can't happen for a woman because they feel shy that they'll be regarded as prostitutes."-unmarried 21-year-old male

As a result, many young women perceive their role as one of serving their partner's sexual needs. This cultural norm limits young women's ability to negotiate the terms of their sexual relationships.

Because intimate partner violence has its roots in socially constructed gender norms, ${ }^{20}$ we attempted to understand these norms so that we could contextualize violence. We asked participants about community perceptions of "ideal" men and women. Most female respondents described an ideal woman as one who is "settled." Young women who are not in school are expected to remain at home unless they need to leave the house. Many women expressed fear that they would be seen as "unsettled" if they took a walk or left the house without a specific purpose.

"An ideal woman is the one who stays at home, is a woman who is settled, being busy at home. Even if she's employed, when she comes from work she continues with her work and is settled at home. People regard this woman as an ideal woman."-unmarried 17-year-old female

Relatives may use violence as punishment for young women who deviate from prescribed behaviors. According to an unmarried 16-year-old female, "When she's found sitting with people who aren't known to the family she's beaten, when she comes from school she comes inside."

Young women place great value on community perceptions of their character. They fear being the source of community gossip, because of the impact that this may have on their opportunities for finding an eligible husband.

"If you are not married then you should be settled. You are supposed to settle down to get a fiancée who will like your character."-unmarried 20-year-old female 
Both women and men say women must be "enduring" and "forgiving" to deal with hardships in life and relationships:

"A woman who is ideal is the one who endures, respects her marriage, loves her family and the community in general and is able to have children. These are the characteristics of ideal women."-unmarried 24-year-old male

\section{Violence and Infidelity}

- Sexual infidelity among youth is common. Young men and women describe a great deal of infidelity in their relationships. The way youth used the word in Kiswahili referred to engaging in sexual relationships with partners other than their primary partner. A primary partner was defined as someone a respondent had been with for at least three months and was committed to above all others.

Most of the young men interviewed said they had multiple concurrent or serial relationships. More often then not, the men said they had had unprotected intercourse despite knowing that they were putting their partners and themselves at risk for HIV. Young women also reported multiple sexual partnerships, although they did so less frequently than the men in our sample. Although few women admitted their own infidelities, men talked about their experiences with women who had other partners.

Because infidelity is so common, men and women described deep mistrust of partners:

"I don't trust my fellow and he doesn't trust me, so we plan that we should go for a test (for HIV). It's not easy to trust each other because the youths of these days don't settle down; one may lie to you while he has another woman apart from you."-unmarried 23-year-old female

Despite the frequency of infidelity, several informants reported being committed to faithfulness in their relationships. Fear of HIV/AIDS is one of the major motivators for maintaining monogamous relationships:

"I don't have another partner apart from this one that I described. I don't have others because there are many things that make one not have another. AIDS is a big problem, so if I have outside partners and then my partner has other partners and those partners have other partners, then you may find yourself getting diseases from other places." -unmarried 19-year-old male

-Violence is condoned by many youth. When asked about their involvement in violence, youth most commonly reported hitting, slapping, punching and kicking. Many of the men and some of the women condoned such behavior under certain conditions. Several young men said men are justified in using violence to control a wife or a long-term partner; with a casual partner, they considered it best to simply end the relationship.

"If he wants to live with her then he can use force to take her back to the characteristics that he thinks are good. So the force may lead even to beat her, it's ok. However, if he has no plans then he can just leave her and look for another one." -unmarried 24-year-old male

According to male respondents, violence is also justified when women lie to their partners, when women make pub- lic things that men consider private, and when there are disagreements about financial matters. Men also described violence as a tool to teach a partner right from wrong.

"There's a time that she refused to tell me but when I beat her she agreed he was her partner. That's the basis of not having faith with these women. These women, there's time they need a teaching, because there are many women that have many men."-married 20-year-old male

However, other young men felt that violence could not be justified under any circumstance.

"There is no need of getting into a relationship and then you start fighting. When there's force in love then it's no longer love, because love is the consent of two people coming together."-unmarried 19-year-old male

- Infidelity is a catalyst for violence. Men and women identified infidelity-whether real or suspected-as the most common trigger for violence in their relationships. Men became violent when they suspected their partner of unfaithfulness or when their partner confronted them about their own sexual infidelities.

All of the male participants who condoned violence or reported violence in their relationships also said that infidelity justifies the use of violence.

"When a woman isn't faithful, there's a need to use force. There's a need to slap her twice or thrice to know that she wronged and correct herself."-married 23-year-old male

Several young women also considered infidelity a justification for men's violence toward their female partners.

"For example, when he guesses that you have a certain boy. When he calls you, then you deny while it's true. So when he finds you, he must use violence a bit."-unmarried 19-year-old female

A few men described experiences in which their partners had confronted them about their own infidelity.

"One day she found me with a girl standing on the road. Therefore, when she came there and wanted to fight, I forbade her. When I forbade her she turned to me and started beating me. I got angry and beat her very severely. I beat her and then we left."-married 20-year-old male

Women also described situations in which they had been physically abused for confronting men about their infidelities.

"He had another woman while I was five months pregnant.... I was passing on a road that he didn't want me to pass because he didn't want me to see him. He was with his friend (partner), and telling me not to pass at the road. So I insisted and passed by that road. When I passed, I said he was the father of this (showing her child). He attacked and started beating me."-unmarried 20-year-old female

\section{Forced Sex}

- Forced sex is narrowly defined by men. Our interviews with young men made clear that many hold a very narrow definition of what can be defined as "forced sex." Several men reported that they had never forced a woman into sex, but then narrated a story in which they became physically violent with their partner to "persuade" her to have sex. Many 
men felt that only forceful intercourse could be categorized as forced sex. One man said he beat his partners when they refused his sexual advances:

"When you find that she doesn't agree you give some beating. If she agrees you make love, and if she doesn't agree you leave her."-unmarried 24-year-old male

This informant, when asked later in the interview, reported that he had never forced a woman to have sex:

I: "Have you used force to make love to a woman?"

P: "That I have never done. When we want to make love, we just do that and she doesn't refuse. I have never done that."

Another young man described using physical violence to "persuade" a reluctant female partner to have sex:

I: "Have you used force to make love to a woman?"

P: "I did that once...I persuaded her with all means but she refused, I lured her but she refused. Because we were in the room I told her she couldn't leave the room until we made love, but she continued to refuse. Therefore, I caught her and you know that girls are weak somehow. When I caught and undressed her she agreed and we made love." -unmarried 23-year-old male

Young men use other strategies as well to encourage reluctant partners to have sex. These include gifts and the promise of financial security. When asked if he had ever forced a woman into sex, one unmarried 23-year-old male tried to clarify what type of force the interviewer meant: "There are many ways of force (power). Some use body power to rape, some use money, you see?"

- Circumstances considered justifications for forced sex. The situation young men most frequently cited as a justification for force was a lengthy period during which a female partner had refused a man's sexual advances. Men also considered it appropriate to punish an unfaithful partner by forcing her to have sex.

"You know when a woman gets another man, use force to make sure that you get what you want." -married 20-yearold male

Forced sex was considered justified more in the context of marital relationships than in nonmarital relationships. Some young men said that when married, men-and sometimes women as well-have a right to have sex with their partner. Therefore, they considered force to be justified when a marital partner refused.

"It's only to a wife where you can force her because there's no other place where he can get the love except his wife and the wife also has no other place except her husband. Therefore, they can all be forced to make love. Even a woman can use force because it's her basic right to make love." -unmarried 21-year-old male

Nevertheless, men also described using force against some nonmarital partners. According to a few young men, some women are "used to" being forced into sexual intercourse.

"Yes, but usage of force is caused by the girls or women by themselves. You may find that someone needs to make love and she's lingering, playing tricks, it gets difficult to withstand that and you have to use force. In addition, when you use force she agrees to make love.... She may even come to your room but she can't undress by herself. You have to use force so that you make love. It's their character and you have to catch her, they are used to it, when you catch her then you make love to her."-married 24-year-old male

Some young men, however, strongly felt that women have sexual rights that should be upheld:

"It's not allowed to make love to a woman by force. This is against the rights of the women. To make love needs the consent of the two people."-unmarried 24-year-old male

Youth who felt that the use of violence and forced sex could not be justified under any circumstances were likely to be those who had not yet initiated sexual relationships or who were in monogamous partnerships.

Most of the male informants who cited situations in which violence against female partners could be justified also identified situations in which forced sex could be justified. Furthermore, the majority of men who admitted being violent in their relationships also described forcing a partner to have sex.

\section{LIMITATIONS}

This study has a number of limitations. Through our interviews, we learned that because of strict parental controls, some young women do not socialize in public venues. The experiences of these young women were therefore not reflected in our data and may differ greatly from the experiences of the young women whom we were able to interview. In addition, our cross-sectional study design captured youth at only one point in time. It would be useful to discuss sensitive topics with young people in depth over time and to capture and describe experiences as they are happening and perhaps changing for youth.

\section{DISCUSSION}

Our previous research in this setting found a strong association between women's HIV status and their prior history of violence in relationships. Young HIV-positive women reported significantly more violence in their relationships than young HIV-negative women. ${ }^{21}$ Although a growing body of literature provides evidence of such an association, the mechanisms through which it operates remain unclear. Some possible hypotheses suggest that violence limits women's ability to negotiate HIV preventive behaviors, ${ }^{22}$ that violent men are less likely to use condoms, ${ }^{23}$ that violent men are more likely than nonviolent men to be HIVpositive ${ }^{24}$ that the physical trauma from forced sex results in a higher risk of HIV transmission during intercourse ${ }^{25}$ and that women who have experienced violence as children are more likely to engage in HIV risk behaviors as an adolescent and adult. ${ }^{26}$

This qualitative study was conducted to further explore the mechanisms through which HIV and violence may be linked in the relationships of young people. The resulting findings suggest that the association we found between HIV and violence in our quantitative study may be mediated by 
suspected or actual sexual infidelity. Infidelity and fear of infidelity are the major triggers for violence in the relationships of young people. Sexual infidelity is also an important risk factor for HIV infection among youth. Women who resist sexual advances from their partners because they fear HIV infection may be forced to have sex by their partners.

Another explanation for the association between women's history of violence and their HIV infection status may lie in women's experiences with forced sex. In our earlier research, we did not find an association between women's experiences with forced sex and their HIV infection status. However, our qualitative findings show that youth narrowly define force during sex as physically holding a woman down and performing forced intercourse. Thus, previous studies may not have been accurately capturing the occurrence of forced sex.

Using physical aggression and other methods to "persuade" reluctant partners to have sexual intercourse was commonly reported in this study. Furthermore, men who reported using violence in their relationships were more likely both to condone forced sex and to report having forced a partner to have sex. Thus, forced sex may account in part for the association between violence and HIV risk.

Finally, this study indicated that the expectations that young women be "settled, enduring and forgiving" underlie their experiences with both sexual infidelity and violence. These norms limit women's ability to confront partners about sexual infidelities and to resist unwanted sexual advances that put them at risk for HIV. These same norms make it difficult for women to leave violent partners.

\section{CONCLUSIONS}

The more nuanced understanding that these data provide on links between HIV and violence among young women has implications for programs and research. Given the vulnerability of youth to HIV in settings like Tanzania, there is an urgent need for HIV prevention programs that specifically target youth. Adolescence is a period in which young men and women begin to form their belief systems, pattern their behaviors and begin initiating intimate relationships-and thus, an ideal time to challenge common notions of violence, reproductive and sexual health. ${ }^{27}$

For these reasons, innovative programs that work with young people to challenge their norms regarding both sex and violence are needed. HIV prevention interventions that fail to take into account the realities of infidelity, violence and forced sex in youth's sexual relationships will have a limited impact.

Equally important, some young men practiced monogamy and condoned neither violence nor forced sex. Program planners need to study and learn from young men who have not accepted traditional gender norms. Young men who felt that the use of violence and forced sex could never be justified generally had not yet initiated a sexual relationship, which highlights the importance of intervening with young men at ages before they become sexually active.
Currently, few HIV and violence prevention interventions target young men. ${ }^{28}$ The outcomes of these programs suggest the importance of a few common elements, such as separating men by age because of the great differences in levels of maturity and experience among youth, ${ }^{29}$ extending interventions over a period of several months or years to achieve sustained impact, ${ }^{30}$ and including out-ofschool youth. ${ }^{31}$

Unfortunately, few of these programs have been rigorously evaluated. Programs need to be coupled with rigorous evaluation designs that can measure the impact of the various program elements and describe specific pathways to change. In addition, collection of longitudinal data would allow researchers to examine how young people's attitudes and behaviors change over time and in response to different experiences.

\section{REFERENCES}

1. Maman S et al, The intersections of HIV and violence: directions for future research and interventions, Social Science \& Medicine, 2000, 50(4):459-478; Garcia-Moreno C and Watts C, Violence against women: its importance for HIV/AIDS. AIDS, 2000, 14(Suppl. 3):S253-S265; Zierler S and Krieger N, Reframing women's risk: social inequalities and HIV infection, Annual Review of Public Health, 1997, Vol. 18, pp. 401-436; van der Straten A et al., Sexual coercion, physical violence, and HIV infection among women in steady relationships in Kigali, Rwanda, AIDS and Behavior, 1998, 2(1):61-73; and Jewkes K et al, Gender inequalities, intimate partner violence and HIV preventive practices: findings of a South African cross-sectional study, Social Science $\&$ Medicine, 2003, 56(1):125-134

2. Dunkle K et al., Gender-based violence, relationship power, and risk of HIV infection in women attending antenatal clinics in South Africa. Lancet, 2004, 363(9419):1415-1421.

3. Maman S et al., HIV-positive women report more lifetime partner violence: findings from a voluntary counseling and testing clinic in Dar es Salaam, Tanzania, American Journal of Public Health, 2002, 92(8): 1331-1337.

4. van der Straten A et al., 1988, op. cit. (see reference 1).

5. Dunkle et al, 2004. op. cit. (see reference 2).

6. Maman S et al, 2000, op. cit. (see reference 1).

7. Garcia-Moreno C and Watts C, 2000, op. cit. (see reference 1); Wingood G. and DiClemente R, The effects of an abusive primary partner on the condom use and sexual negotiation practices of AfricanAmerican women, American Journal of Public Health, 1997, 87(6):10161018; and Zierler S and Krieger N, 1997, op. cit. (see reference 1).

8. Central Intelligence Agency, Tanzania, World Factbook, 2004, $<$ http://www.odci.gov/cia/publications/factbook>, accessed Nov. 8, 2004; and United Nations Population Fund (UNFPA), Partnering: A New Approach to Sexual and Reproductive Health, Technical Paper, 2000, New York: UNFPA, No. 3.

9. United Nations Children Fund (UNICEF), State of the World's Children, 2003, <http://www.unicef.org/sowc00>, accessed Jul. 14, 2003.

10. Tanzania National AIDS Control Program, National AIDS Control Programme HIV/AIDS/STD Surveillance, Report No. 13, 1999.

11. Population Reference Bureau, The World's Youth 2000, 2000, <https://www.prb.org>, accessed Jul. 17, 2003.

12. Mwakigile D, Sexual behavior among youths at high risk for HIV1 infection in Dar es Salaam, Tanzania, Sexually Transmitted Infections, 2001, 77(4):255-259.

13. National AIDS Control Programme, Tanzania; MEASURE and Bureau of Statistics, Tanzania, AIDS in Africa During the Nineties: Tanzania, Chapel Hill, NC, USA: Carolina Population Center, University of North Carolina at Chapel Hill, 2001.

14. Ibid. 
15. Mwakigile D et al., 2001, op. cit. (see reference 12).

16. Creighton C and Omari C, eds., Gender, Family and Household in Tanzania, Brookfield, VT, USA: Avebury, 1995.

17. Holland J et al., The Male in the Head: Young People, Heterosexuality and Power, London: Tufnell Press, 1998.

18. Pulerwitz J et al., Relationship power, condom use and HIV risk among women in the USA, AIDS Care, 2002, 14(6):789-800.

19. Shephard B, Masculinity and the male role in sexual health, Planned Parenthood Challenges, 1996, 2(2):11-14

20. Instituto Promundo, Guy to Guy Project: Engaging young men in violence prevention and in sexual and reproductive health, Rio de Janeiro, Brazil: Instituto Promundo, 2002.

21. Maman S et al., 2002, op. cit. (see reference 3).

22. Ibid.

23. Taquette $S$ et al., Violent relationship in young people and STD/AIDS risk, Cadernos de saude publica, 2003, 19(5):1437-1444.

24. Dunkle Ket al., 2004, op. cit. (see reference 2).

25. Maman S et al., 2002, op. cit. (see reference 3).

26. Ibid.

27. Archer J, Gender roles as developmental pathways, British Journal of Social Psychology, 1984, 23(3):245-256, Kindler H, Developmentalpsychology aspects of work with boys and men, paper presented at the first European conference on Sex Education for Adolescents, Federal Centre for Health Education (Germany), 1995; Erikson E, Identity: Youth and Crisis, New York, W.W. Norton, 1968; Ross J, What Men Want: Mothers, Fathers and Manhood, Cambridge, MA: Harvard University Press, 1994; and World Health Organization (WHO), What About Boys: A Literature Review on the Health and Development of Adolescent Boys, Geneva: WHO, 2000

28. Hayward R, Some organizations working with men and boys to end violence against women and girls, New York: UNICEF, 2001

29. Irvin A, Taking Steps of Courage: Teaching Adolescents about Sexuality and Gender in Nigeria and Cameroon, New York: International Women's Health Coalition, 2000

30. Ibid.

31. Hemstead R, Working with adolescent boys, programme experiences: consolidated findings from regional surveys in Africa, the Americas, Eastern Mediterranean, South-East Asia, and Western Pacific Geneva: WHO, 2000

\section{RESUMEN}

Contexto: Trabajos de investigación previos han indicado una sólida correlación entre la infección del VIH y la violencia sexual, en particular entre el grupo de mujeres jóvenes. Sin embargo, aún no es bien comprendido el papel de la violencia en las relaciones sexuales de los jóvenes en la región del África Subsahariana.

Métodos: Entrevistadores locales capacitados realizaron entrevistas semi-estructuradas a 40 hombres y 20 mujeres, de 16-24 años, que fueron escogidos de lugares públicos en Dar es Salaam, Tanzania.

Resultados: Los participantes describieron las interacciones complejas que hay en sus relaciones sexuales entre la violencia, el sexo forzado y la infidelidad. Asimismo, los hombres que se comportaban con violencia hacia sus parejas con frecuencia mencionaron que el sexo forzado y la infidelidad sexual caracterizaban dicha relación. Los hombres que tenian múltiples pare- jas sexuales al mismo tiempo indicaron que se volvían violentos cuando su pareja les cuestionaba su fidelidad y manifestaron que forzaban a sus parejas a mantener relaciones sexuales cuando ellas se resistían frente a sus avances. Los jóvenes que manifestaron que bajo ninguna circunstancia se podia justificar la violencia y el sexo forzado, generalmente eran aquellos que aún no habian iniciado sus relaciones sexuales o que tenían relaciones monógamas.

Conclusiones: La asociación entre el VIH y la violencia identificada entre los jóvenes en trabajos de investigación anteriores se puede explicar parcialmente por la experiencia con la infidelidad y el sexo forzado en las relaciones intimas. Las intervenciones para la prevención del VIH que no tomen en cuenta la infidelidad, la violencia y el sexo forzado, los cuales ocurren con frecuencia en las relaciones sexuales de los jóvenes, tendrán definitivamente un impacto muy limitado.

\section{RÉSUMÉ}

Contexte: La recherche antérieure a démontré une forte corrélation entre l'infection à VIH et les antécédents de violence par un partenaire intime, parmi les jeunes femmes surtout. Le rôle de la violence dans les relations sexuelles des jeunes d'Afrique subsaharienne n'est cependant pas bien compris.

Méthodes: Des intervieweurs formés localement ont mené des entrevues semi-structurées avec 40 jeunes hommes et 20 jeunes femmes de 16 à 24 ans recrutés en divers endroits publics de Dar es Salaam, en Tanzanie.

Résultats: Les participants ont décrit de complexes interactions entre la violence, la contrainte sexuelle et l'infidélité dans leurs relations sexuelles. Les hommes violents à l'égard de leurs partenaires féminines ont aussi souvent fait état de contrainte et d'infidélité sexuelle dans leurs relations. Les hommes à partenaires sexuelles multiples concomitantes ont déclaré devenir violents lorsque leurs partenaires féminines mettent en doute leur fidélité, et contraindre leurs partenaires ordinaires à avoir des rapports sexuels lorsqu'elles résistent à leurs avances. Les jeunes qui estimaient injustifiables, sous aucun prétexte, la violence et la contrainte sexuelle étaient souvent ceux encore vierges ou en relation monogame.

Conclusions: L'association entre VIH et violence identifiée parmi les jeunes dans le cadre de la recherche antérieure s'explique en partie par leur expérience de l'infidélité et de la contrainte sexuelle dans leurs relations intimes. Les interventions de prévention du VIH qui ne tiennent pas compte de l'infidélité, de la violence et de la contrainte sexuelle souvent présentes dans les relations sexuelles des jeunes ne pourront avoir qu’un impact limité.

\section{Acknowledgments}

The research on which this article is based was supported by grants from the Horizons Project and the Interagency Gender Working Group of the U.S. Agency for International Development.

Author contact:smaman@jhsph.edu 